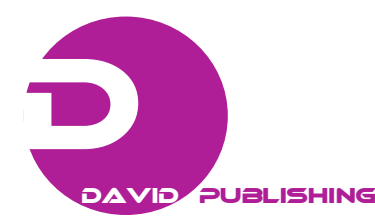

\title{
Real Estate Evaluation in Germany
}

\author{
Otmar Schuster and Hanns-Florian Schuster \\ GEOhaus-House of Geoinformation, Muelheim at the Ruhr, Germany
}

\begin{abstract}
The real estate market is at risk to produce economic bubbles, which produce heavy financial losses while bursting. To flatten these bubbles, Germany tried since the 1960s a way of thorough analysis and high transparency of the real estate market as a public task. The experts from different professions in the local market effectively are included in a honorary form. The competition between the experts and also between the experts and the public institution is intentionally maintained.
\end{abstract}

Key words: Real estate valuation, committees of experts on real estate evaluation, purchasing price data base, BauGB (Federal Building Code).

\section{Introduction}

The human activities in the real estate market happen to be limited by the laws and public regulations in every country.

Very often we find situations, where there is a great difference between the legal activity and the practical experience.

For the ownership real estate often means power in the society one has to exercise care for equality before the law and to serve up justice.

People have a very fine feeling for unjust regulations and institutions being corrupted or sickly by partiality.

So the people demand a great deal of the institutions in terms of authenticity and credibility in the daily work, plausibility in regulations and reliability over long time [1]. Shortly, the institutions must be worthy to creed in them.

This is more than a wordplay, which demands a lot from the people in the institutions and of course also of the regulations to be performed.

\section{Transparency in the Real Estate Market}

One of the demands directed upon the institutions

Corresponding author: Hanns-Florian Schuster, public appointed surveyor, research fields: IUS and technique. E-mail: hanns.schuster@geohaus.de. in the real estate market is to establish transparency. Transparency is an irremissable prerequisition for reaching credibility in the population. This transparency ends there, where the freedom of contract of every acting human being begins. This again is a high good in a market economy and democracy, because this is one motor on the human economic activity.

The dividing lines between these demands vary in the countries of Europe slightly, but in one point they demand the same: the real estate market shall be on hand for everybody in a way which is beneficial for all in the economy and democracy [2].

\section{The Committees of Experts on Real Estate Valuation in Germany}

In Germany, there are independently public authorities, which provide transparency on the real estate market-the committees of experts on real estate valuation (Gutachterausschuss für Grundstückswerte). These committees connect private-economical know-how of real estate experts with the independence and competence of a public authority—without any political influence or control.

The members are appointed by the state. They are appointed in the form of a honorary appointment, which means that they get a small compensation of costs but no full remuneration. 
$\S 192$ BauGB (Federal Building Code) [3] decrees that the chairperson and the committee members shall have both, expertise and experience in determining property values and in valuation of other kinds, and shall not be otherwise involved on a full-time professional basis with the management of property in the territorial entity for which the committee of experts has been formed. In order to determine standard land values, an official from the competent tax revenue authority with experience in assessing property for tax purposes is to be made available as an expert.

Each committee is an independent group of experts, which is not subordinated to political or other supervision. Their work is supported by an office, which is set up in the municipal or state administration. The employees of this office are payed by the public corporation they belong to. The head of the office and the employees are not bound by instructions of the public corporation in terms of their technical duties.

This distinctive feature is a perhaps unimposing but important barrier for wielding power of big public institutions on their employees.

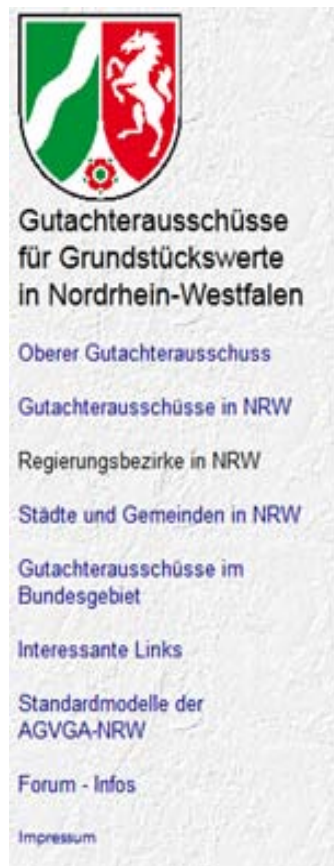

Informationen zum Grundstùcksmarkt Regierungsbezirke in NRW

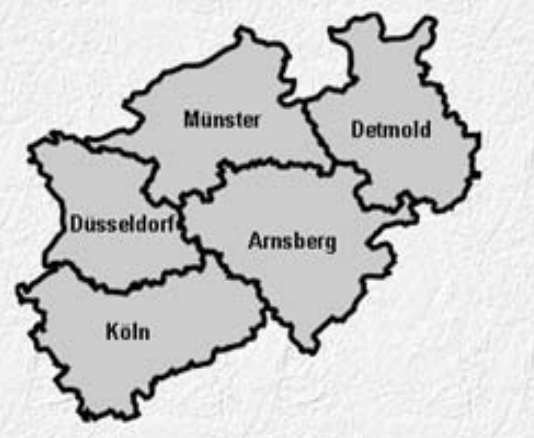

Das enweiterte Angebot der Gutachterausschüsse und des Oberen Gutachterausschusses för Grundstuckswerte zum Immobilienmarkt in NRW. Zu den bewathrten Produkten (Bodenrichtwerte, Grundstucksmarktberichte) kommen neue hinzu: Bodenwertubersichten und eine Preisauskunt for Wohnimmobilien.

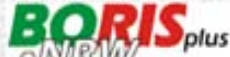

\section{The Duties of the Committee of Valuation Experts}

The BauGB decrees in § 193 the following duties:

The committee of experts shall produce expert opinions of the current market values of properties both, with and without buildings, and of rights to property, where this is requested by:

(1) the authorities charged with enforcing this Act in the execution of their duties under this act;

(2) the authorities responsible for assessing the value of a property or the level of compensation due in respect of a property or a right to a property on the basis of other statutory provisions;

(3) the owners or persons with equivalent rights, holders of other rights to the property and persons entitled to a compulsory portion, where the value of the property is significant for assessing the value of the portion;

(4) courts and judicial authorities.

Nothing shall-so in clause 5-affect entitlements under other statutory provisions in respect of requests or applications.

\section{Fig. 1 The site of the committee of valuation of Northrhine-Westphalia (www.boris.nrw.de).}


Further, in addition to producing expert opinions on the level of compensation due in the case of loss of a right, the committee of experts may produce opinions on the level of compensation in respect of property loss of other types. This opens possibilities to impact economic life, but they are often underestimated.

The committee of experts shall compile data on purchasing prices, which it shall analyze to establish standard ground values and other data required in valuation, i.e., weighted average cost of capital (cap rate or property yield), real asset value factors, conversion coefficients, comparable factors for valuation (like building factor or earnings factors).

The expert opinions are not binding where nothing has been agreed or determined to the contrary. But this often is the case in the private legal relations.

A copy of the expert opinion is to be sent to the property owner. This shows the eminent role of the owner in that law. Private expert opinions follow that only in case their commissioner has asked for doing so.

Further works are to be performed like:

(1) informing of clients about standard ground values;

(2) derivation of residential rent tables.

The establishment of expert opinions about rent and lease has great value for residential and real estate objects.

\section{The Standardized Market Value}

Amid the German valuation process stands the definition of the standardized market value without any doubt:

The standardized market value is defined as the price, which would be achieved in an ordinary transaction at the time when the assessment is made, taking into account the existing legal circumstances and the actual characteristics, general condition and location of the property or other object of assessment, without consideration being given to any extraordinary or personal circumstances.

\section{Purchasing Price Data Base}

In order to enable the compilation of purchasing price data, a copy of each contract by means of which a person enters into an obligation to convey property for payment or in exchange, or to establish a lease, shall be sent by the office, where this is recorded (normally the notary) to the committee of experts. This also applies to the offer and acceptance of a contract, where this has been recorded separately, and to agreements before an expropriation authority, resolutions on expropriations, resolution on the anticipation of a decision within proceedings on land reallocation, resolutions on the preparation of reallocation plans, resolutions on boundaries, and to the surcharge in the case of compulsory auction proceedings in respect of immovable property.

\section{Evaluation of the Sales Contracts}

The office of the committee of experts evaluates the data of the sales contracts using mathematical or statistical methods. This is not an easy work and needs a lot of knowledge and experience because the contracts often comprise personal implications or commitments. The purchase price data base has to be free from such distortions.

\section{Standard Ground Values}

An assessment shall be made on the basis of the purchasing price data base of average local ground values for each section of the municipal territory, taking due account of varying degrees of development; as a minimum requirement, such assessment shall be made in respect of building land, which either has been exempted from recoupment charges for public infrastructure or in respect of which such charges are due (standard ground values). In areas where building has taken place, standard ground values are to be assessed as if the ground had not been built on. Where nothing has been determined to the contrary, standard ground values are to be assessed at the end of each 

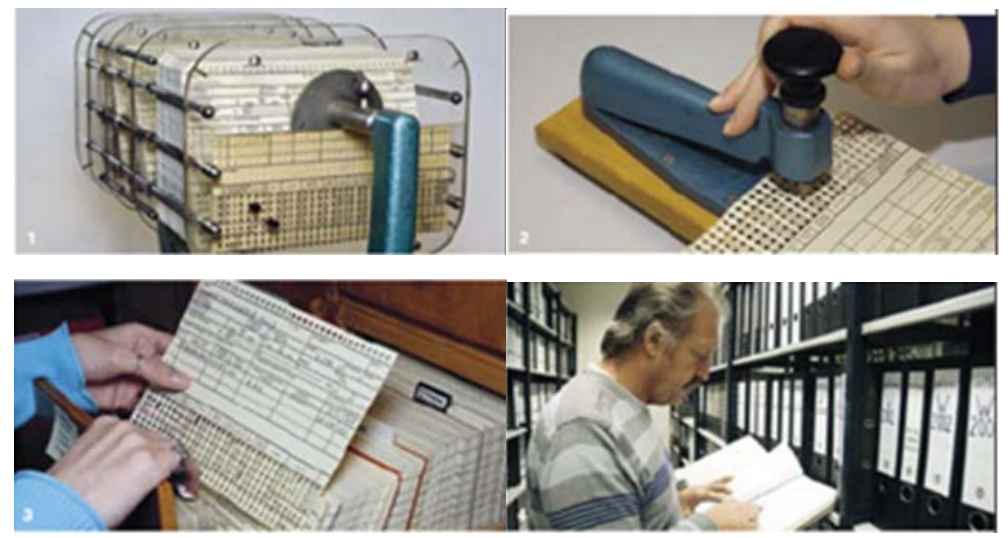

Fig. 2 Purchasing price data base in a development over 50 years in Hamburg and now hidden in a modern database.
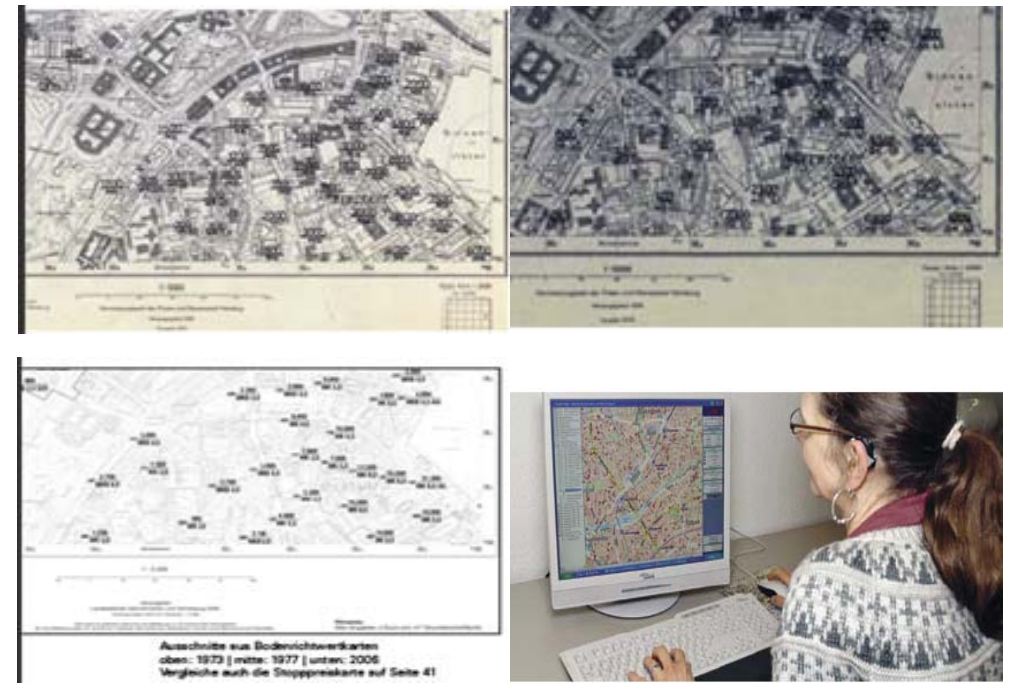

Fig. 3 Standard ground values and the technical progress over 50 years in Hamburg [4].

calendar year. Standard ground values for purposes of the valuation of economic units for property for purposes of taxation (Einheitsbewertung) shall be assessed at the principal time of reference as applicable. At the request of the authorities charged with the enforcement of the BauGB, standard ground values shall be assessed for individual localities as of some other point in time.

Where land quality within an area has been changed as a result of a legally binding land use plan or of some other measure, the subsequent updating of standard ground values on the basis of the changes in quality shall also include an assessment of standard ground values to reflect values at the time of the previous valuation of economic units for property for taxation purposes. This assessment need to be made to the relevant tax authorities.

Standard ground values shall be published and notification made to relevant tax authorities. Information on standard ground values is to be made freely available to the public from the offices of the committee of experts.

\section{New Zones of Standard Ground Values}

On the basis of the youngest regulations concerning the committees of experts, all committees in the Federal Republic are busy with the densification of standard ground values and to define the zone boundaries for these values. This division into small sections shall provide better value expertises and a better handling by private and public users and additionally without ordering an experts opinion. 


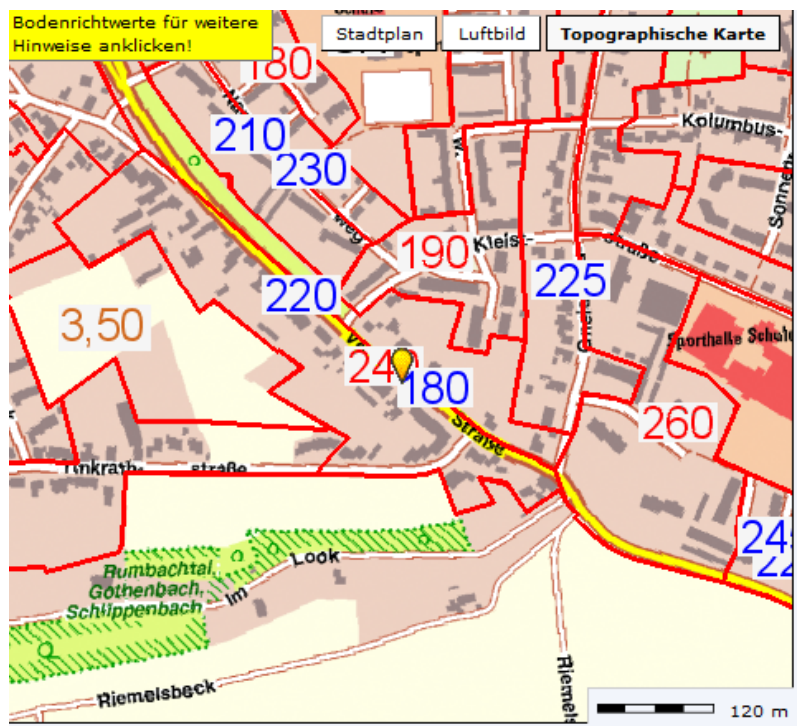

Fig. 4 The new zones for standard ground values 2011.

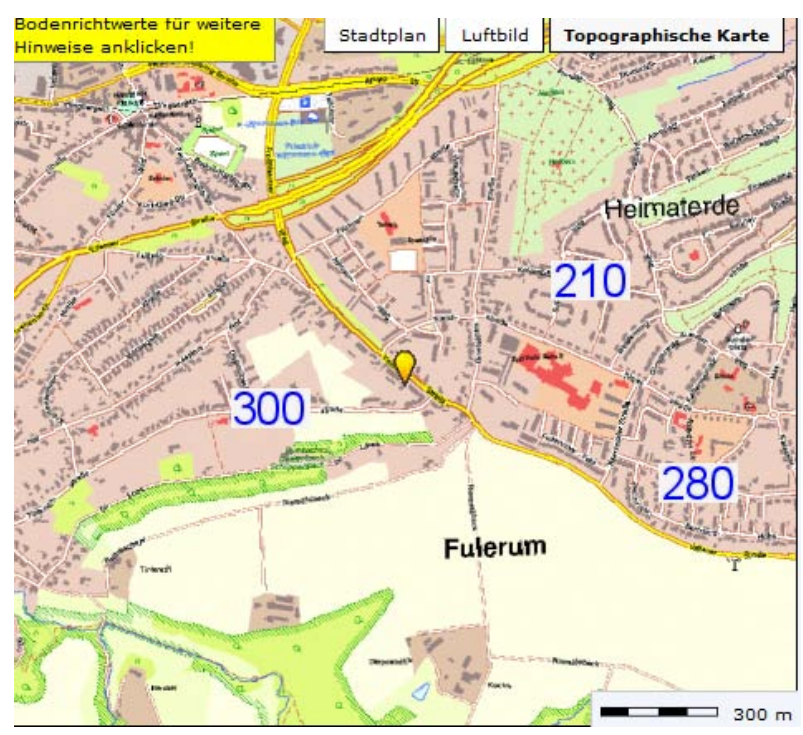

Fig. 5 The old standard ground values 2010.

\section{The Power of the Committee of Experts}

A look into the law is worthwhile: the committee of experts may gather information orally or in writing from persons with specialist knowledge, and from those persons who are in a position to provide information concerning the property in question, and, where this is required in order to assess the level of payment due within reallocation proceedings, as a compensatory settlement or as compensation for expropriation information concerning a property which is being used for purposes of comparison. The committee may require that owners and other holders of rights to property submit the document required for compilation of purchasing price data and for the production of an expert opinion. Owners of, and holders of rights to property are obliged to tolerate the inspection of their property for purpose of assessment of purchasing prices and the preparation of expert opinions. Dwellings may only be entered with the permission of the occupier.

All courts and authorities are obliged to provide the committee of experts with administrative and legal cooperation. The tax authority shall provide information on property, where this is required for the assessment of compensatory payments and of compensation for expropriation.

This regulation shows that the committee has a high reputation inside the public authority. At the same time it is able to get the necessary data from the owners or holders of rights.

\section{Varying Implementation in the Federal States of Germany}

The Federal Republic is well known for the originality of the 16 states and so there are in 16 states 16 slightly different solutions of the basic federal regulations under the roof of the federal law. The "Laender" is mostly responsible for the performance of such general laws.

In the BauGB there are two steps of delegation:

- The Federal Government with the approval of the Federal Council is authorized to impose regulations by statutory orders to ensure the application of the same principles in both the assessment of the current market values and the derivation of the data required for assessment. For this, the German Federal Ordinance for Valuation (ImmowertV [5]) was decreed. It contents the valuation methods like the depreciated replacement cost method or the income (capitalization) approach to valuation, the comparative method, etc.;

- The federal state governments are authorized to regulate by means of statutory orders: 
(1) the formation and the activities of committees of experts where this has not already been performed in the federal law BauGB and the role to be played in individual cases by experts and by a committee;

(2) the duties of the chairperson;

(3) the setting up and the duties of the committee's offices;

(4) the compilation and analysis of purchasing price data, the assessment of standard ground values and the publication of standard ground values or other valuation data, and the provision of information derived from the purchasing price data;

(5) the communication of data from the farmland reallocation and consolidation department for purposes of the compilation and the analysis of purchasing price data;

(6) the transfer of other duties to the committee of experts and the higher committee of experts, and remuneration to members of the committee of experts.

Even if the basis is the same, this leads to different solutions in praxis. Since the experts from different states work together in many gremiums, the solutions are said to have the same level of quality.

\section{The Frame of the Expert Opinion with Regard to the Contents}

For the reproducibility, comparability and the usability before a court it is necessary that the expert opinion has a notional structure, which is judicially and economically comprehensible, traceable and reproducible. The basis in Germany is laid by the German Civil Code, the systematic of the Land Registration Code, the definitions of the BauGB and the tasks defined there. The expert opinions are deeply influenced by the systematic and the wording of the Federal Land Utilization Ordinance (BauNVO). They give the possibility to generalize publicly planned utilization and real utilization, so that it can be understood in the whole country.

This possibility using legally defined items in the expert opinions and in the private legal relations, eases the work of the experts and is therefore very important.

This becomes more clear, if you compare the American way of performing this work. An American Due Diligence for sale, rent or building lease in the concept of the so-called "Estoppel-Certificate" [6] has to define many items, which are in Germany defined by public regulations.

Other parts of the frame of contents are due to the building. Statistical data concerning costs and descriptions of generalized buildings are standardized as well as the depreciation because of age.

The expert has to describe the deviations in a clear way and in so far the comparability is given.

This complex but securely given leads to similar results, makes the results controllable and promotes the usability at the court.

\section{Publicly Planned Utilization and Real Use}

The expert opinions must deal with the publicly planned utilization [7] and the real use of the property. The private utilization has to follow the public planned utilization. The value of property depends very much from its use or the legal possibility to use it. Therefore the expert must know the wording of the public planning world and its impact. A utilization of a property, which is in contrary to the legally binding land use plan has an administrative finality over the remaining life expectancy of the building [8].

In the commercial area, such plots are extremely precious, where city relevant goods are allowed to be sold. The renting prices are double as high as normal residential renting prices. Therefore, there is a lot of discussion in politics as well as before the court about these definitions. In the centre of these definitions it stands the $\S 11$ (3) of the Land Utilization Ordinance (BauNVO [9]), especially the impact of special markets on existing structures.

The expert has to take notice of such mixed and unclear situations, which makes his tasks not easy. 


\section{Private Experts and the Committee of Experts}

The committee of experts consists mostly of private freelancers or other experts. Therefore the competition situation is mitigated and occupies seldom political discussions. Private experts find to be distinguished, to be assigned as member of the committee.

Nonetheless, a competition situation in terms of expert opinions is given. The public or private commissioner can elect the service person or institution, if not other conditions are given.

In Germany there are a lot of different experts for real estate valuation: the sworn experts, publicly appointed by the chambers of commerce or the engineering chambers, the publicly appointed surveying engineers or many sorts of privately certified experts.

\section{Conclusions}

During the 50 years of influencing the real estate market by these methods Germany succeeded in flattening the bubbles successfully. Germany could avoid the heavy losses of the economy by the work of privates under a public shelter in a democratic and economic way.

\section{References}

[1] Baldur Kirchner: Benedikt for Manager, Gabler Publishing House.

[2] Atzinger \& Partners, International Law Firm: Real Estate Guide 2006.

[3] BauGB $=$ German Federal Building Law.

[4] Festschrift 50 Years Real Estate Experts Committee, Hamburg.

[5] ImmowertV = Decree for Real Estate Evaluation, at July 1st 2010 the ImmowertV replaced the former decree (WertV).

[6] FAZ - Institute: Immobilienkapitalmarket 2011-ius in reasl etstate, ius of investments \& Co.: Developments, Risks and Chances.

[7] Federal Ministry for Planning, Building and Urban Development: Law and Practice of Urban Development in the Federal republic of Germany, 1993.

[8] The Federal Minister of Regional Planning, Building and Urban Development: Papers \& Solutions Concerning the Federal Land Utilisation Ordinance 1988.

[9] BauNVO = Federal Land Utilisation Ordinance from 23.1.1990 with the recent change at 22. 4. 1993. 